\title{
ULASAN PERATURAN:
}

\section{INSTRUKSI PRESIDEN REPUBLIK INDONESIA NOMOR 8}

\author{
TAHUN 2018 TENTANG PENUNDAAN DAN EVALUASI \\ PERIZINAN PERKEBUNAN KELAPA SAWIT SERTA \\ PENINGKATAN PERKEBUNAN KELAPA SAWIT (INPRES
}

\section{MORATORIUM SAWIT)}

\author{
Henri Subagiyo ${ }^{321}$ dan Astrid Debora S.M ${ }^{322}$
}

\section{Pendahuluan}

Pada tanggal 19 September 2018 lalu, Presiden menerbitkan Instruksi Presiden (Inpres) Nomor 8 Tahun 2018 tentang Penundaan dan Evaluasi Perizinan Perkebunan Kelapa Sawit serta Peningkatan Perkebunan Kelapa Sawit atau lazim disebut Inpres Moratorium Sawit. Keluarnya Inpres ini dilatarbelakangi oleh beberapa persoalan mendasar dalam perkebunan kelapa sawit, antara lain lemahnya tata kelola perkebunan kelapa sawit yang berkelanjutan, kepastian hukum, kelestarian lingkungan hidup termasuk penurunan emisi Gas Rumah Kaca, perlunya pembinaan petani kelapa sawit, dan peningkatan produktivitas kelapa sawit.

Patut diakui bahwa sektor perkelapasawitan selama ini telah memberikan kontribusi bagi Indonesia. Namun di sisi lain, berbagai persoalan yang muncul mulai dari tingkat lokal, nasional hingga internasional tidak dapat pula diabaikan. Berbagai persoalan tersebut setidaknya telah menjadi isu penting yang semakin berkembang hingga menimbulkan reaksi internasional, khususnya rencana Uni Eropa untuk melarang impor minyak kelapa sawit dari Indonesia.

${ }^{321}$ Henri Subagiyo adalah Direktur Eksekutif Indonesian Center for Environmental Law.

322 Astrid Debora S.M adalah Peneliti dan Deputi Monitoring, Evaluasi, dan Manajemen Pengetahuan Indonesian Center for Environmental Law. 
Greeenpeace mencatat selama periode 2015-2017 terjadi deforestasi seluas 1,6 juta ha dimana 19 persen terjadi di konsesi kelapa sawit. ${ }^{323}$ Data ini menjustifikasi bahwa ekspansi sawit telah memberikan pengaruh pada deforestasi.

Di sisi lain, Menteri Lingkungan Hidup dan Kehutanan RI menyatakan telah mengidentifikasi sekitar 15 juta ha lahan di kawasan hutan. Dari 15 juta ha tersebut, 11 juta ha tercatat sebagai lahan perkebunan termasuk kelapa sawit. Sedangkan dari 11 juta ha tersebut teridentifikasi hanya sekitar 2,3 juta ha yang memiliki izin perkebunan sawit. 324

Pada bulan Mei 2016, Menteri Perdagangan Thomas Lembong menyebutkan bahwa 40 persen dari total 11 juta ha lahan persebunan kelapa sawit produktivitasnya rendah.
Oleh karena itu, dengan moratorium yang berarti menghentikan ekstensifikasi lahan, diharapkan pemerintah dapat menfokuskan pada peningkatan produktivitas. ${ }^{325}$

Beberapa permasalahan di atas melatarbelakangi terbitnya Inpres Moratorium Sawit. Diharapkan, dengan terbitnya Inpres ini memberikan semangat baru bagi upaya untuk terus memperbaiki tata kelola hutan dan lahan.

\section{Materi Muatan Moratorium Sawit Inpres Moratorium Sawit} memberikan perintah kepada beberapa Menteri terkait, yaitu: Menteri Koordinator Bidang Perekonomian, Menteri Lingkungan Hidup dan Kehutanan, Menteri Pertanian, Menteri Agraria dan Tata Ruang/Kepala Badan Pertanahan Nasional, Menteri Dalam

\footnotetext{
${ }^{323}$ Tane Hadiyantono, "Polemik Inpres Moratorium Lahan Sawit, “https://industri.kontan.co.id/news/polemik-inpres-moratorium-lahan-sawit, diakses pada 25 Oktober 2018.

324 Andri Donnal Putera, "Moratorium Kebun Kelapa Sawit, izin di 2,3 Juta Hektar Lahan Dievalusi", https://ekonomi.kompas.com/read/2018/10/19/125834526/moratorium-kebun-kelapasawit-izin-di-23-juta-hektar-lahan-dievaluasi, Lihat juga https://economy.okezone.com/read/2018/10/19/320/1966224/menteri-lhk-evaluasi-izin-2-3-jutaha-lahan-sawit, diakses pada 31 Oktober 2018.

325 Septian Deny, "Ini Alasan Pemerintah Ingin Moratorium Izin Lahan Kelapa Sawit", https:// www.liputan6.com/bisnis/read/2516363/ini-alasan-pemerintah-ingin-moratorium-izinlahan-kelapa-sawit, diakses pada 25 Oktober 2018.
} 
ULASAN PERATURAN: INSTRUKSI PRESIDEN REPUBLIK INDONESIA NOMOR 8

TAHUN 2018 TENTANG PENUNDAAN DAN EVALUASI PERIZINAN PERKEBUNAN KELAPA SAWIT SERTA PENINGKATAN PERKEBUNAN KELAPA SAWIT

(INPRES MORATORIUM SAWIT)

Negeri, Kepala Badan Koordinasi

Penanaman Modal, Para Gubernur,

dan Para Bupati/Walikota. Masingmasing memiliki tugas dan tanggung jawab sesuai dengan bidang kerjanya. 326

1. Menteri Koordinator Bidang Perekonomian

Menteri Koordinator Bidang

Perekonomian

bertanggungjawab

untuk

melakukan

koordinasi

penundaan dan evaluasi

perizinan perkebunan kelapa

sawit serta peningkatan

produktivitas perkebunan

kelapa sawit. Kegiatan-kegiatan

yang wajib dilakukan dalam

rangka pelaksanaan koordinasi

tersebut antara lain:

a. Memverifikasi data pelepasan atau tukar menukar kawasan hutan untuk perkebunan kelapa sawit, peta Izin Usaha Perkebunan atau Surat
Tanda Daftar Usaha Perkebunan, Izin Lokasi, dan Hak Guna Usaha (HGU);

b. Menetapkan standar minimun kompilasi data;

c. Melakukan sinkronisasi dengan pelaksanaan Kebijakan Satu Peta yang berkaitan dengan kesesuaian: perizinan yang dikeluarkan oleh kementerian/lembaga dengan pemerintah daerah, Izin Usaha Perkebunan dengan HGU, dan keputusan penunjukan atau penetapan Kawasan hutan dengan HGU;

d. Menyampaikan hasil rapat koordinasi kepada Menteri, gubernur, dan/atau bupati/walikota terkait dalam rangka pengambilan keputusan sesuai kewenangannya mengenai: (1) penetapan kembali areal

${ }^{326}$ Indonesia. Instruksi Presiden tentang Penundaan dan Evaluasi Perizinan Perkebunan Kelapa Sawit Serta Peningkatan Perkebunan Kelapa Sawit. Inpres Nomor 8 Tahun 2018, Bagian KesatuKetujuh. 
yang berasal darik hutan yang telah dilakukan pelepasan atu tukar menukar kawasan hutan sebagai kawasan hutan;

penetapan areal yang berasal dari kawasan hutan yang telah dilakukan pelepasan sebagai tanah negara; (3) norma, standar, prosedur, dan kriteria (NSPK) Izin Usaha Perkebunan atau Surat Tanda Daftar Usaha Perkebunan; (4) penetapan tanah terlantar dan penghentian proses penerbitan atau pembatalan HGU; dan/atau (5) langkahlangkah hukum dan/atau tuntutan ganti rugi atas penggunaan Kawasan hutan untuk perkebunan kelapa sawit berdasarkan verifikasi data dan evaluasi atas pelepasan atau tukar menukar kawasan hutan untuk perkebunan kelapa sawit.
2. Menteri Lingkungan Hidup dan Kehutanan

Menteri Lingkungan Hidup dan Kehutanan bertanggung jawab untuk:

a. Melakukan penundaan pelepasan atau tukar menukar kawasan hutan untuk perkebunan kelapa sawit bagi: (1) permohonan baru; (2) permohonan yang telah diajukan namun belum melengkapi persyaratan atau telah memenuhi persyaratan namun berada pada kawasan hutan yang masih produktif, atau (3) permohonan yang telah mendapat persetujuan prinsip namun belum ditata batas dan berada pada kawasan hutan yang masih produktif.

Penundaan tersebut dikecualikan untuk permohonan pelepasan atau tukar menukar kawasan hutan untuk perkebunan kelapa sawit yang telah ditanami dan diproses 
ULASAN PERATURAN: INSTRUKSI PRESIDEN REPUBLIK INDONESIA NOMOR 8

TAHUN 2018 TENTANG PENUNDAAN DAN EVALUASI PERIZINAN PERKEBUNAN KELAPA SAWIT SERTA PENINGKATAN PERKEBUNAN KELAPA SAWIT

(INPRES MORATORIUM SAWIT)

berdasarkan ketentuan Pasal

51 PP 104 Tahun 2015 tentang

Tata Cara Perubahan

Peruntukan dan Fungsi

Kawasan Hutan.

b. Melakukan penyusuan dan verifikasi data pelepasan atau tukar menukar kawasan hutan untuk perkebunan kelapa sawit yang mencakup: nama dan nomor, lokasi, luas, peruntukan, dan tanggal penerbitan.

c. Melakukan evaluasi terhadap: (1) pelepasan atau tukar menukar Kawasan hutan yang dimanfaatkan sebagai perkebunan kelapa sawit yang belum dikerjakan/dibangun, masih berupa hutan produktif, dan/atau terindikasi tidak sesuai dengan tujuan pelepasan atau tukar menukar dan dipindahtangankan pada pihak lain; (2) perkebunan kelapa sawit yang berada dalam kawasan hutan tetapi belum mendapatkan pelepasan atau tukar menukar kawasan hutan; (3) pelaksanaan pembangunan areal hutan yang bernilai konservasi tinggi (High Conservation Value Forest (HCVF) dari pelepasan kawasan hutan untuk perkebunan kelapa sawit, Hasil evaluasi tersebut disampaikan kepada Menteri Koordinator Bidang Perekonomian.

d. Melakukan identifikasi perkebunan kelapa sawit yang terindikasi berada dalam kawasan hutan.

e. Menindaklanjuti hasil rapat koordinasi dengan Menteri terkait mengenai: penetapan kembali areal yang berasal dari kawasan hutan yang telah dilakukan pelepasan atau tukar menukar kawasan hutan sebagai kawasan hutan; dan/atau (2) langkah-langah hukum dan/atau tuntutan 
ganti rugi sesuai ketentuan peraturan perundangundangan atas penggunaan kawasan hutan untuk perkebunan kelapa sawit berdasarkan verifikasi data, evaluasi atas pelepasan atau tukar menukar kawasan hutan untuk perkebunan kelapa sawit.

f. Melakukan identifikasi dan melaksanakan ketentuan alokasi $\quad 20 \% \quad$ untuk perkebunan rakyat atau pelepasan kawasan hutan untuk perkebunan kelapa sawit.

3. Menteri Pertanian Menteri Pertanian bertanggung jawab untuk:

a. Menyusun dan memverifikasi data dan peta Izin Usaha Perkebunan Kelapa Sawit dan pendaftaran Surat Tanda Daftar Usaha Perkebunan Kelapa Sawit secara nasional mencakup: nama dan nomor, lokasi, luas, tanggal penerbitan, peruntukan, luas tanam, dan tahun tanam.

b. Melakukan evaluasi terhadap: (1) proses pemberian Izin Usaha Perkebunan dan pendaftaran Surat Tanda Daftar Usaha Perkebunan Kelapa Sawit; (2) Izin Usaha Perkebunan dan Surat Tanda Daftar Usaha Perkebunan Kelapa Sawit yang telah diterbitkan; dan (3) pelaksanaan kewajiban perusahaan perkebunan yang memiliki Izin Usaha Perkebunan Kelapa Sawit atau izin usaha perkebunan untuk budidaya kelapa sawit untuk memfasilitasi pembangunan kebun masyarakat paling kurang 20\% dari total luas areal lahan yang diusahakan oleh perusahaan perkebunan.

Hasil evaluasinya disampaikan kepada Menteri Koordinator Bidang Perekonomian. 
c. Menindakanjuti hasil rapat koordinasi mengenai NSPK Izin Usaha Perkebunan atau Surat Tanda Daftar Usaha Perkebunan.

d. Meningkatkan pembinaan kelembagaan petani sawit dalam rangka optimalisasi dan intensifikasi pemanfaatan lahan untuk peningkatan produktivitas sawit.

e. Memastikan setiap perkebunan kelapa sawit untuk menerapkan standar Indonesian Sustainable Palm Oil (ISPO).

4. Menteri Agraria dan Tata Ruang/Kepala Badan

Pertanahan Nasional

Menteri Agraria dan Tata Ruang/Kepala Badan Pertanahan Nasional

bertanggung jawab untuk:

a. Menyusun dan memverifikasi data HGU yang mencakup: nama dan nomor, lokasi, luas, anggal penerbitan, dan peruntukan. b. Melakukan evaluasi terhadap : (1) kesesuaian HGU perkebunan kelapa sawit dengan peruntukan tata ruang; (2) realisasi pemanfaatan HGU perkebunan kelapa sawit; (3) peralihan HGU kepada pihak lain tanpa pendaftaran Badan Pertanahan Nasional; dan (4) pelaksanaan perlindungan dan/atau pembangunan areal hutan yang bernilai konservasi tinggi/HCVF dari pelepasan kawasan hutan untuk perkebunan kelapa sawit.

Hasil evaluasinya disampaikan kepada Menteri Koordinator Bidang Perekonomian.

c. Menindaklanjuti hasil rapat koordiasi mengenai: penetapan tanah terlantar yang berasal dari pelepasan atau tukar menukar kawasan hutan sesuai ketentuan peraturan perundangundangan; (2) penghentian 
proses penerbitan HGU dalam hal proses perolehan haknya tidak dilakukan sesuai ketentuan peraturan perundang-undangan atau pembatalan HGU perkebunan kelapa sawit yang telah ditetapkan sebagai tanah terlantar; (3) pengembalian tanah yang berasal dari pelepasan atau tukar menukar kawasan hutan sebagai kawasan hutan sesuai ketentuan peraturan perundangundangan apabila belum diproses dan/atau diterbitkan Hak Atas Tanahnya; (4) penetapan tanah yang berasal dari pelepasan kawasan hutan sebagai tanah negara sesuai ketentuan peraturan perundang-undangan; dan (5) pengembalian tanah yang berasal dari pelepasan atau tukar menukar kawasan hutan disampaikan kepada gubernur untuk diusulkan kepada Menteri Lingkungan Hidup dan Kehutanan menjadi kawasan hutan.

d. Melakukan percepatan penerbitan hak atas tanah kepada masyarakat dalam rangka pelaksanaan hak masyarat seluas $20 \%$ dari pelepasan kawasan hutan dan dari HGU perkebunan kelapa sawit.

e. Melakukan percepatan penerbitan hak atas tanah pada lahan-lahan perkebunan kelapa sawit rakyat.

5. Menteri Dalam Negeri

Menteri Dalam Negeri bertanggung jawab untuk melakukan pembinaan dan pengawasan kepada gubernur dan bupati/walikota dalam pelaksanaan penundaan dan evaluasi perizinan perkebunan kelapa sawit, serta peningkatan produktivitas perkebunan kelapa sawit.

6. Kepala Badan Koordinasi Penanaman Modal 
ULASAN PERATURAN: INSTRUKSI PRESIDEN REPUBLIK INDONESIA NOMOR 8

TAHUN 2018 TENTANG PENUNDAAN DAN EVALUASI PERIZINAN PERKEBUNAN KELAPA SAWIT SERTA PENINGKATAN PERKEBUNAN KELAPA SAWIT

(INPRES MORATORIUM SAWIT)

Kepala Badan Koordinasi

Penanaman Modal bertanggung jawab untuk menunda permohonan penanaman modal baru untuk perkebunan kelapa sawit atau perluasan perkebunan kelapa sawit yang telah ada, yang lahannya berasal dari pelepasan atau tukar menukar kawasan hutan, kecuali yang menjadi tanggung jawab Menteri Lingkungan Hidup dan Kehutanan

7. Gubernur

Gubernur bertanggung jawab untuk:

a. Melakukan penundaan penerbitan

rekomendasi/izin usaha perkebunan kelapa sawit dan izin pembukaan lahan perkebunan kelapa sawit baru yang berada pada kawasan hutan, kecuali yang menjadi tanggung jawab Menteri Lingkungan Hidup dan Kehutanan.

b. Mengumpulkan dan memverifikasi data dan peta izin lokasi dan izin usaha perkebunan atau Surat Tanda Daftar Usaha Perkebunan yang mencakup: nama dan nomor, lokasi, luas, tanggal penerbitan, peruntukan, luas tanam, dan tahun tanam.

c. Menyampaikan hasil pengumpulan dan verifikasi kepada Menteri Pertanian (yang menyangkut Izin Usaha Perkebunan) dan Menteri Agraria dan Tata Ruang/Kepala Badan Pertanahan Nasional (yang menyangkut Izin Lokasi).

d. Menindaklanjuti rekomendasi hasil rapat koordinasi mengenai pembatalan Izin Usaha Perkebunan atau Surat Tanda Daftar Usaha Perkebunan yang berada di dalam kawasan hutan.

e. Menyampaikan usulan kepada Menteri Lingkungan Hidup dan Kehutanan untuk penetapan areal yang berasal 
dari pengembalian tanah dari pelepasan atau tukar menukar kawasan hutan menjadi kawasan hutan.

8. Bupati/Walikota Bupati/Walikota bertanggung jawab untuk:

a. Melakukan penundaan penerbitan rekomendasi/izin usaha perkebunan kelapa sawit dan izin pembukaan lahan perkebunan kelapa sawit baru yang berada pada kawasan hutan, kecuali yang menjadi tanggung jawab Menteri Lingkungan Hidup dan Kehutanan.

b. Mengumpulkan data dan memetakan seluruh area perkebunan pada wilayah kabupatennya yang diusahakan oleh badan usaha maupun perseorangan, yang mencakup peruntukan, luas tanam, dan tahun tanam.

c. Mengumpulkan data dan peta serta memverifikasi Izin
Lokasi dan Izin Usaha Perkebunan atau Surat Tanda Daftar Usaha Perkebunan yang mencakup: nama dan nomor, lokasi, luas, tanggal penerbitan, peruntukan, luas tanam, dan tahun tanam.

d. Mengumpulkan data dan peta perkebunan rakyat pada wilayah kabupatennya yang berada pada kawasan hutan dan di luar kawasan hutan (Area Penggunaan Lain).

e. Menyampaikan hasil pengumpulan data kepada gubernur dengan tembusan kepada Menteri Pertanian, Menteri Lingkungan Hidup dan Kehutanan, dan Menteri Agraria dan Tata Ruang/Kepala Badan Pertanahan Nasional.

f. Menindaklanjuti rekomendasi hasil rapat koordinasi mengenai pembatalan Izin Usaha Perkebunan atau Surat Tandar Daftar Usaha 
ULASAN PERATURAN: INSTRUKSI PRESIDEN REPUBLIK INDONESIA NOMOR 8

TAHUN 2018 TENTANG PENUNDAAN DAN EVALUASI PERIZINAN PERKEBUNAN KELAPA SAWIT SERTA PENINGKATAN PERKEBUNAN KELAPA SAWIT

(INPRES MORATORIUM SAWIT)

Perkebunan yang berada di dalam kawasan hutan.

Sebagai koordinator, Menteri

Koordinator Bidang Perekonomian melaporkan pelaksanaan Inpres ini kepada Presiden secara berkala setiap 6 (enam) bulan atau sewaktu-waktu diperlukan. ${ }^{227}$ Sebagai penutup, Inpres ini memerintahkan bahwa pelaksanaan penundaan perizinan perkebunan kelapa sawit dan evaluasi atas perizinan perkebunan kelapa sawit yang telah diterbitan, dilakukan paling lama 3 (tiga) tahun sejak Inpres ini dikeluarkan dan pelaksanaan peningkatan produktivitas kelapa sawit dilakukan secara terus menerus. ${ }^{328}$

\section{Catatan Kritis Inpres}

\section{Moratorium Sawit: Prasyarat}

\section{Keberhasilan}

Diskursus mengenai kebutuhan moratorium kelapa sawit sesungguhnya telah berlangsung lama. Tidak heran, ketika Presiden pada September lalu menerbitkannya, beberapa kalangan, terutama masyarakat sipil yang peduli terhadap isu perbaikan tata kelola hutan dan lahan mengapreasiasinya.

Inpres Motarorium Sawit hanyalah langkah awal dalam mewujudkan tata kelola perkebunan sawit yang ramah lingkungan. Terdapat beberapa prasyarat bagi keberhasilan pelaksanaan Inpres ini.

\section{A. Sinkronisasi Data Perizinan}

\section{Antar Sektor dan Data Lapangan}

Dalam melakukan evaluasi usaha perkebunan kelapa sawit memerlukan sinkronisasi berbagai data perizinan dan pendukungnya, misalnya izin lokasi, Amdal atau UKL-UPL, izin lingkungan, izin usaha perkebunan, izin pelapasan kawasan hutan, Hak Guna Usaha, dan sebagainya. Selain itu juga dibutuhkan verifikasi kesesuaian data lapangan dari aktifitas perkebunan yang ada. Oleh karena itu, ketersediaan dukungan data menjadi sangat penting. Berdasarkan pengalaman Program Review Perizinan Kegiatan Ekstraktif (Hutan, 
Tambang, dan Kebun) yang dilakukan

oleh ICEL bersama dengan jaringan organisasi masyarakat sipil di beberapa daerah tahun 2015-2018, banyak ditemukan indikasi bahwa pemerintah, khususnya pemerintah daerah tidak memiliki dukungan ketersediaan data perizinan. Lemahnya database perizinan akan menjadi tantangan terbesar pada kegiatan ini.

\section{B. Penegakan Hukum}

Berbagai pelanggaran perkebunan sawit sesunguhnya bukanl hal yang baru. Tantangan terbesar bukan pada identifikasi pelanggaran, melainkan bagaimana menindaklanjuti berbagai temuan pelanggaran yang ada. Sebagai contoh, Panitia Khusus Monitoring Perizinan dan Lahan Perkebunan DPRD Provinsi Riau tahun 2016 telah menemukan ribuan hektar hutan digarap secara ilegal oleh 33 (tiga puluh tiga) perusahaan perkebunan sawit. Temuan ini telah dilaporkan kepada Kepolisian dan Kejaksaan. Namun hingga saat ini belum jelas bagaimana kelanjutan penegakan hukum yang dilakukan oleh aparat penegak hukum. ${ }^{329}$

Koalisi Eyes on the Forest, pada tahun 2017 menemukan 10 (sepuluh) perusahaan perkebunan sawit yang terindikasi berada dalam Kawasan hutan. Diperkirakan luas 10 (sepuluh) perusahaan yang teridentifikasi sekitar 73.047 ha dan hanya memiliki HGU sekitar 40.005 ha. Hal ini berarti, ada penanaman kebun di luar hak yang diberikan. Ironisnya, izin HGU tersebut ada yang berada pada kawasan hutan. ${ }^{330}$ Bahkan pada bulan Maret 2017, Pansus DPRD Provinsi Riau menyatakan terdapat 1,8 juta ha perkebunan sawit dari total 4,2 juta ha yang terindikasi tanpa izin pelepasan kawasan hutan dan diperkirakan merugikan negara sebesar 34 Triliun

329 M. Syukur, "Apa Kabar Kasus 33 Perusahaan Sawit Perambah Hutan Riau?", https:// www.liputan6.com/regional/read/2830617/apa-kabar-kasus-33-perusahaan-sawitperambah-hutan-riau, diakses pada 1 November 2018.

${ }^{330}$ EoF Investigative Report, “Kebun sawit beroperasi dalam kawasan hutan di Provinsi Riau tanpa izin maupun pelanggaran lainnya", https://www.eyesontheforest.or.id/reports/kebun-sawitberoperasi-dalam-kawasan-hutan-di-provinsi-riau-tanpa-izin-maupun-pelanggaran-lainnya, diakses pada 1 November 2018. 
ULASAN PERATURAN: INSTRUKSI PRESIDEN REPUBLIK INDONESIA NOMOR 8

TAHUN 2018 TENTANG PENUNDAAN DAN EVALUASI PERIZINAN PERKEBUNAN KELAPA SAWIT SERTA PENINGKATAN PERKEBUNAN KELAPA SAWIT

(INPRES MORATORIUM SAWIT)

hanya dari kehilangan nilai pajak. ${ }^{331}$

Sayangnya, hingga saat ini belum jelas bagaimana tindak lanjut penegakan hukum terhadap pelanggaran tersebut.

Titik tekan materi Inpres Moratorium lebih kepada evaluasi perizinan melalui sinkronisasi data perizinan dan data lapangan. Sayangnya, Inpres Moratorium ini tidak mengatur secara rinci mengenai tindak lanjut pasca dilakukannya evaluasi. Tidak ada instruksi terhadap lembaga penegak hukum dalam Inpres tersebut. Padahal stagnan-nya penegakan hukum selama ini menjadi kendala terbesar dalam membereskan persoalan pelanggaran perkebunan sawit yang terjadi.

Belajar dari pengalaman review perizinan yang dilakukan oleh ICEL tahun 2015-2018, terdapat beberapa tipologi pelanggaran perkebunan sawit yang membutuhkan penanganan yang berbeda meskipun sebagian besar memerlukan tidak lanjut penegakan hukum. Beberapa tipologi tersebut antara lain:

1. Pelanggaran akibat persoalan kebijakan atau konflik regulasi. Misalnya, usaha perkebunan sudah ada sebelum penetapan kawasan hutan atau adanya konflik penetapan kawasan hutan dengan rencana tata ruang wilayah. Terhadap tipe pelanggaran seperti ini diperlukan kebijakan transisi hingga waktu tertentu dengan dapat dibarengi disinsentif, termasuk memulihkan kerusakan yang diakibatkan oleh usahanya tersebut sepanjang tidak ditemukan adanya pelanggaran prosedural yang dilakukan oleh pelaku usaha;

2. Pelanggaran administrasi perizinan. Misalnya izin usaha yang dikeluarkan meskipun jelas-jelas berada di kawasan hutan ataupun dikeluarkan

${ }_{331}$ Chaidir Anwar Tanjung, "1,8 Juta Ha Kebun Sawit di Riau Ilegal, Negara Rugi Rp 34 Triliun", https://news.detik.com/berita/d-3436256/18-juta-ha-kebun-sawit-di-riau-ilegal-negara-rugi-rp-34-triliun, diakses pada 1 November 2018. 
dengan melanggar ketentuan prosedur izin yang berlaku. Terhadap pelanggaran seperti ini perlu didalami kemungkinan adanya praktek-praktek korupsi di balik pelanggaran administrasi tersebut. Dalam hal ini ada banyak kasus yang dapat dijadikan contoh, salah satunya praktek korupsi yang melibatkan mantan Gubernur Annas Maamun tahun 2016 atas suap alih fungsi kawasan hutan untuk perkebunan kelapa sawit. Terhadap kasus seperti ini juga diperlukan tindakan hukum yang berkonsekusi terhadap para pelaku usaha karena keterlibatannya dalam praktek korupsi perizinan.

3. Pelanggaran usaha tanpa izin atau pelaksanaan usaha yang melanggar kewajiban izin. Terhadap tipe ini perlu dilakukan penegakan hukum secara tegas untuk memulihkan dampak akibat pelanggaran yang dilakukannya sekaligus sebagai bentuk upaya memberikan efek jera (deterrent effect) bagi pelanggar maupun pendidikan kepada publik.

\section{Peran Serta Publik}

Peran serta publik dalam moratorium sawit sangat diperlukan bagi keberhasilan pelaksanaan Inpres ini meskipun tidak diatur di dalamnya. Beberapa alasan mengapa peran serta publik diperlukan, antara lain:

1. Evaluasi yang dilakukan berdasarkan Inpres ini utamanya untuk mengidentifikasi adanya pelanggaran yang sangat mungkin hal ini terjadi karena kontribusi atau keterlibatan orang dalam, baik pada level keputusan administrasi perizinan, pengawasan maupun penegakan hukum. Oleh karenanya, potensi adanya conflict of interest pun sangat tinggi. Dengan adanya peran serta publik hasil dan proses evaluasi akan memungkinkan bagi publik untuk memberikan informasi, klarifikasi maupun 
ULASAN PERATURAN: INSTRUKSI PRESIDEN REPUBLIK INDONESIA NOMOR 8

TAHUN 2018 TENTANG PENUNDAAN DAN EVALUASI PERIZINAN PERKEBUNAN KELAPA SAWIT SERTA PENINGKATAN PERKEBUNAN KELAPA SAWIT

(INPRES MORATORIUM SAWIT)

melakukan pengawasan selama evaluasi dilakukan mupun tindak lanjutnya, terlebih jika terdapat perbedaan hasil dengan kondisi di lapangan;

2. Debagaimana disampaikan sebelumnya, salah satu tantangan besar bagi pelaksanaan evaluasi ini adalah ketersediaan data di lembaga pemerintah sendiri, khususnya pemerintah daerah. Dengan adanya peran serta publik, dimungkinkan pemerintah untuk mendapatkan input data dan informasi dari publik sehingga memudahkan kerja pemerintah dalam melakukan verifikasi dan menindaklanjuti hasilnya;

3. Dikarenakan salah satu tujuan pelaksanaan Inpres ini untuk memitigasi dampak usaha sawit terhadap lingkungan hidup maupun masyarakat yang merupakan kepentingan publik, maka sudah sewajarnya publik terlibat dalam prosesnya.
Beberapa langkah yang dapat dilakukan Pemerintah dalam mendorong peran serta publik dalam pelaksanan Inpres ini, antara lain:

1. Membentuk kelembagaan tim kerja yang terdiri dari berbagai unsur, selain instansi sektoral pemerintah juga akademisi, praktisi maupun masyarakat sipil. Akademisi, praktisi maupun masyarakat sipil yang ditunjuk akan lebih baik jika terdiri dari berbagai latar belakang yang relevan misalnya pemetaan, pertanian, kehutanan, hukum maupun kalangan organisasi masyarakat sipil yang bergerak di bidang hutan dan lahan. Tim ini selain berada di tingkat nasional juga perlu dibentuk untuk tingkat lokal. Selain itu, dapat dipertimbangkan pada tim tersebut unsur-unsur penegak hukum yang relevan untuk mendukung tindak lanjut hasil evaluasi.

2. Membentuk kanal informasi publik. Kanal informasi publik 
sangat diperlukan untuk hanya berlaku 3 (tiga) tahun sejak mendorong peran serta publik diterbitkan atau berakhir pada dalam memberikan masukan September 2021. Oleh karena itu, mengenai data atau informasi di lapangan guna mendukung proses verifikasi yang berjalan. Berbagai kanal publik milik pemerintah yang selama ini ada dapat dioptimalkan, misalnya situs LAPOR (Layanan Aspirasi dan Pengaduan Online Rakyat) melalui

https://www.lapor.go.id/ yang terhubung dengan berbagai kementerian maupun situs atau aplikasi pengaduan lainnya yang dimiliki oleh kementerian.

\section{Agenda Kerja dan Target yang}

\section{Terukur}

Mengingat Inpres ini muncul di akhir periode Pemerintahan Presiden Jokowi-JK, banyak kalangan yang sebetulnya meragukan hasil dari kebijakan ini dalam waktu dekat. Terlebih lagi tahun 2019 adalah tahun politik yang kemungkinan besar menyita banyak kerja dan perubahan situasi politik. Di sisi lain Inpres ini agenda kerja dan target terukur yang disepakati oleh tim maupun diketahui publik sangat diperlukan.

Selain itu, pendekatan kerja secara pararel sangat diperlukan, misalnya untuk tipe-tipe pelanggaran yang jelas dan nyata perlu segera dilakukan tindak lanjut tanpa menunggu semua proses usaha selesai di evaluasi. Langkah ini diperlukan mengingat proses penegakan hukum umumnya membutuhkan waktu yang tidak singkat dan langkah ini diperlukan khususnya bagi pelanggaran yang menimbulkan dampak secara lingkungan maupun sosial masyarakat.

\section{IV.Penutup: Pekerjaan Rumah terkait Implementasi Inpres Moratorium \\ Sawit}

Meskipun memiliki kelemahan dalam pengaturannya, Inpres Moratorium Sawit mau tidak mau wajib dijalankan oleh pihak terkait agar tujuan yang diharapkan dapat tercapai. Keberhasilan agenda penting yang 
ULASAN PERATURAN: INSTRUKSI PRESIDEN REPUBLIK INDONESIA NOMOR 8

TAHUN 2018 TENTANG PENUNDAAN DAN EVALUASI PERIZINAN PERKEBUNAN KELAPA SAWIT SERTA PENINGKATAN PERKEBUNAN KELAPA SAWIT

(INPRES MORATORIUM SAWIT)

diatur Inpres Moratorium Sawit sangat ditentukan oleh strategi implementasi yang mumpuni dari penerima mandat pada akhir periode Pemerintahan Jokowi-JK. Karenanya, selain ada beberapa prasyarat keberhasilan di atas, beberapa pekerjaan rumah yang perlu dituntaskan untuk mendukung pelaksanaan Inpres Moratorium Sawit, diantaranya:

1. Penegasan kembali mengenai peran aparat penegak hukum (polisi dan jaksa) serta unit kerja teknis di Kementerian terkait yang membidangi penegakan hukum. Tanpa adanya penegakan hukum yang baik, akan sulit memberikan efek jera bagi pelaku-pelaku pelanggaran dan kejahatan sawit serta kawasan hutan dan lahan.

2. Pemerintah wajib menata kembali bisnis 'persawitan' dari hulu hingga hilir. Pemerintah juga perlu memperhatikan pertumbuhan usaha perkebunan lainnya, tidak hanya bergantung pada komoditas sawit saja.
3. Perlu adanya review kebijakan menyeluruh yang berpengaruh sebagai faktor pemicu bagi pelanggaran-pelanggaran di bidang perkebunan sawit. Misalnya aspek kebijakan tumpang tindih tata ruang, perlindungan kawasan ekosistem penting seperti gambut, sistem perizinan, ISPO, dan lain-lain.

4. Keterbukaan informasi dan pelibatan publik dalam kebijakan moratorium sawit. Publik yang selama ini menaruh perhatian terkait dengan hutan dan lahan perlu dilibatkan untuk memperkuat proses input dan akuntabilitas dari agendaagenda penting selama moratorium berjalan. 